\title{
The Impact of Human Resources Management Activities on Employees Loyalty in Private Organizations in Saudi Arabia
}

\author{
Sami A. Albahussain
}

\begin{abstract}
It has become increasingly important for organizations to make sure that they engage their employees in activities and programs which further encourage them to perform and reach their optimum potential in achieving the goals and the objectives of the organization, and more importantly, to stay loyal to the organization. The loss of employees to resignations is one of the major causes of increase in the overhead and training expenses of a organization, and it is important for organizations to explore into possible ways that they can guarantee employee loyalty. HRM is also an important stakeholder, and much of the efforts in maintaining employee loyalty should come from the department which understand employee needs the most.

This study aims to delve into the concepts of employee loyalty, including the factors which motivate the employees to stay with the organization. The study employs a quantitative approach into the said factors, with the categories explored in the quantitative survey comprising of general loyalty motivators, personal motivators, HR relations, and $H R$ and management activities motivators. A survey was conducted among 450 employees of private sector organizations in Dammam, Saudi Arabia, and based on the findings of the study it can be said that the private sector organizations may like to focus on creating conducive atmosphere, and grant maximum fulfillment and contentment which can encourage the employees to enjoy their job and that leads to employees' satisfaction. This is very important in retaining employees.
\end{abstract}

Index Terms-Employees loyalty, human resources management, private organizations, Saudi Arabia.

\section{INTRODUCTION}

In diverse fields and areas of professional careers, and whatever the type of work employees are engage in, the motivation of people employed in it is one of the most important conditions and policies that are established in order for a organization to achieve its goals and objectives. The involvement and the engagement of the employees in the production-based activities of the organization obviously

create positive results, but what keeps the employees engaged in their tasks is explained by the concept of motivation.

Understandably, employees in a workplace are expected to perform tasks and assume responsibilities which are related to the goals that the organization is expecting to reach with the

said employees' participation. According to Kondo [1], the

Manuscript received March 17, 2013; revised May 26, 2013.

Sami Albahussin is with the College of Business Administration, University of Dammam, Saudi Arabia (e-mail: sbahussain@ud.edu.sa). more effort a organization devotes to the development of new products and technology and to the associated quality assurance, the greater scale the activities become and the more these activities contribute to the success of the organization. Usually, this is achieved by standardization systematization and duplication.

However, being obliged to work under rigid rules, regulations and implementing procedures can affect the attitude of the employees. Employees tend to grow apathetic and demotivated with routine, and they lose interest in achieving the goals that they have previously reached. Realistically, aside from contributing to the organization, one of the major reasons why employees engage in their jobs is because they want to get compensated; they want to earn money. The question now is this: what is it apart from money which inspires and motivates people to be productive and to use the paid time efficiently and in a worthwhile fashion?

Aside from profit and positive scores, another determining factor in the success of organizations is its ability to retain its employees. Organizations impose rules and regulations, as well as delegate tasks to their employees. In the daily performance of their job descriptions, employees might grow weary of the repetitiveness of their activities, hence the need for the HR department of the organization to perform intervention strategies in order to convince employees to perform well for the sake of the organization.

\section{LITERATURE REVIEW}

One can argue organization's greatest asset is its labor force. With the amount of skill and competency in the labor force as of late, a good HR manager should be able to cull out the cream of the crop from a pool of applicants to a certain position. After being hired, the employee is eager to work, but what stokes the fire to keep it burning is something that a organization should work on and perfect, especially if turnovers are to be avoided.

This literature review will attempt to create a brief yet comprehensive study on what strategies organizations could engage in order to maintain a steady and loyal pool of employees working for the organization. Aside from the topmost executive affecting the attitudes of the employees towards the organization, the HR managers or the HRD is an important department in making sure that employee retention is kept to a maximum. Turnovers are very expensive for the organization, that's why retention is important. This section will build up on the need for loyal employees and how it could otherwise affect the organization. 


\section{A. Employee Retention}

The measure of loyalty is retention, and the term, in its broader sense, refers to how many of the current employees stay around over a given period of time. According to Carsen [2], the cost of replacing an employee varies but it is predictably expensive. During a turnover, a organization may incur the various start-up costs of hiring someone new, such as administrative expenses and training [2]. Writers such as Carsen [2], and Kaye [3], agree that there are varied definitions of the concept of employee retention.

It could be as simple as "stopping people from leaving the organization" or "it's all about the culture and how [organizations] treat people" or even "presenting a consistent, effective employer proposition across the entire employee life cycle, thus ensuring that [the organization] source, hire, manage and develop employees who partner with us in achieving the organizational goals [3].

Given the definitions, employee retention is synonymous to providing fair, equitable, and attractive employment packages and retention offers which attract employees and encourage them not to leave the organization anymore. It is also important for the management and the administrative body of the organization to lead with an example, in a manner which can set a precedence and a pattern in having the right attitude towards work and the tasks related to it.

\section{B. Employee Motivation}

One can say that one of the biggest determinants of motivation and consequently, employee retention, is human need [4], [5]. Motivation can be attributed to as the "conscious or unconscious stimulus, incentive or motives for action toward a goal resulting from psychological or social factors, the factors giving the purpose or direction to behavior (p.105)" [6]. Similarly, Lauby [7], agree that motivation is the direction of a certain person's behavior, and it "refers to the many possible behaviors in which an employee could engage" (p.1). It is also a person's level of effort, or the level of how hard people work; or person's level of persistence in the face of obstacles [7], [8].

According to Corpuz [9], there are different factors which affect motivation among employees. These include individual differences (personal attributes that are unique to a person), job characteristics (job description, variety of skills involved, degree of completion and autonomy) and organizational practices (rules, HR policies, managerial practices and rewards system of an organization). An interesting insight by Corpuz also says that while most managers and administrators think that money is the top motivator, employees in fact want to feel valued for their contributions. Most of the fundamental elements in employee motivation lies in the well-deserved boosting of morale and self esteem, and it has been proven by studies that praise and recognition motivate employees to put forth their best efforts to perform at higher levels.

\section{Previous Studies}

Various literatures such as the ones written by Sacco [10], Drizin [11] and Woolard [12], all point to the initiatives set by the organization and its HR department as the foremost determinant of employee loyalty. In Sacco [10], a Canadian research firm has proven that there has been an increase in the active participation and the loyalty of IT employees. According to the report, IT employees have proven to be more loyal to their organizations than in 2003, and that the dedication of the said workers has increased drastically. The truly loyal staffers, according to Sacco [10] are the ones who plan to stay with the organization for another two years or more. Furthermore, Sacco [10] wrote that drivers of employee loyalty have not changed since the earlier study. Among the said drivers are: how much care and concern employee show toward their employees, "not only in their career development, but also in helping them balance their work and family lives". Moreover, fair workplace policies, day-to-day satisfaction and reinforcement from managers, along with the compensation also increases the loyalty of the employees to their organizations.

More comprehensively, Drizin [11], wrote about three organizations that have had observed occurrences of an increase in the loyalty among their subjects. Part of the goals of Drizin's case studies were geared towards gaining a better understanding of the critical business value of retaining good employees. In the study, he featured Stalcop L.P. (a small cold-forming metals products manufacture); Gaylor Group, Inc. (a full-serviced electrical contractor serving both industrial and commercial markets); and Roche Diagnostics (a French organization which offers a broad spectrum of innovative healthcare solutions).

In order to retain its employees, Stalcop L.P. implemented strategies which area geared towards creating mentoring programs to help new employees as they transition into the job. Also, the mentorship proved to decrease employee turnover, increase the efficiency and the productivity of the new employees and provide do on-the-job training on both the new employees and their mentors. Part of the action plan is to employ advisory groups, giving employees representation in evaluating survey results and affecting change within the organization. Furthermore, Drizin [11], writes that it has seen both "its employee loyalty and customer satisfaction increase as a result of taking action on issues uncovered in its research".

In another study by Drizin [11], he featured the Gaylor Group, Inc.'s commitment to employee orientation. The said organization is reported to have used different strategies such as investing in the welfare and the development of the employees in different initiatives such as education and training in order to improve the commitment it receives from its employees. The said HR-initiated projects were reported to produce fast results, with the sales increasing by $63 \%$ and the attrition decreasing by nearly $10 \%$ [11]. Lastly, the study on Roche Diagnostics uncovered similar initiatives which were put in place in order to pay closer attention to the hiring, developing and most importantly, retaining a highly educated and skilled employee pool. In order to maintain a low level of attrition, Roche utilized an online survey which focused on acquiring active responses at the rate of $80 \%$. Roche used the feedback in order to cater to the needs of its employees, and also, it developed a quantitative measurement through the Employee Commitment Index, which is an important aspect in the organization's balanced scorecard.

Moving on, basis of this questionnaire is the study 
createdby Tony Schwartz, as was quoted in the report by Woolard [12]. In a nutshell, the study lists down 12 aspects of a great place to work which employees find desirable in a certain organization. According to Woolard [12], the level of compensation, employee involvement, healthy and affordable cafeteria food, safe working environments, rest periods and well-equipped facilities such as gyms or fitness centers are some of the most important determinants of employee loyalty. On the other hand, the management side of the coin is equally important. In order for a workplace to be considered as a great place to work at, it must have defined, clear and specific expectations while providing the employees the autonomy to reach the said desired outcomes. Also, two-way (also 360-degree) performance reviews may also improve the attrition problem of a organization. Accountability from the managers and leaders is also important, and so is providing employees with ongoing opportunities to further develop and enhance their learning. More importantly, organizations must stand for something beyond simply increasing profits.

\section{DATA AND METHODOLOGY}

As this study is investigating the effects and the impacts of human resource department activities on the loyalty of the employees, it can be referred to as a positivist approach. The research strategy is set to be a mono-method approach using a survey [13]. This approach indicates the use of a questionnaire for obtaining the necessary information from the survey conducted among the survey respondents from the private sector of Dammam, Saudi Arabia which can then be applied to the relevant research literature in regards to the previously explained economic management theories.

The research study will include a non-probability convenience sampling strategy to draw a workable sample. Convenience sampling needs to be used and implemented because the premise of the 0073tudy, and the target respondents of the study can only be effectively and exhaustively tested and administered with the questions of this study in the said method. With the effectiveness, as well as the efficiency and the restraints in the resources, the said population cannot be reached effectively by other methods of sampling. The said sampling method will be used due to their satisfactorily accurate results in most cases, if correctly selected and implemented, when used. Also worth noting is that even when the data has substantial heterogeneity, large samples can provide efficient data to make the majority of decisions [13].

The sample for this survey study would be purposively chosen from the database of the Dammam Chamber of Commerce, and will concern different organizations in the private sector. 450 individuals will be surveyed without any regard for the organization they belong to, further reinforcing the non-probability approach of the paper.

The questionnaire that was administered to the client was made concerning the different factors of motivation, as well as questions on the different aspects of employee loyalty. For the study, a Likert Scale will be used in order to rate the response of the employees as Strongly Agree, Agree, Neutral, Disagree and Strongly Disagree. The answers will be quantified in SPSS by converting the said answers into numerical scores as 5, 4, 3, 2 and 1 respectively. The questions can be found in the Appendix of this paper.

\section{Survey Design, Reliability and Validity}

In terms of survey design, the items in the survey was derived by the researcher from the 12 items on the list the Aspect of A Great Place to Work by [12]. According to Woolard [12], there are 12 items which contribute to the loyalty of the employees. Among the said aspects are the following: commit to paying every employee a living wage; give employees a stake in the organization success; design work environments that are safe, comfortable and appealing to work in; provide healthy high quality food at the lowest possible prices; create places for employees to rest and renew during the course of the day; offer a well-equipped gym and other facilities that encourage employees to stay fit; define clear and specific expectations for what success looks like; institute two-way performance reviews; hold leaders and managers accountable for treating employees with respect and care; create policies which encourage employees to set aside time to focus and lastly, stand for something beyond simply increasing profits.

The researcher formulated the questions out of the 12 items that Woolard [12] listed. Woolard's [12], list is comprehensive enough, and it is a well-rounded list of the things that should be present in the workplace in order for the organization to ensure the steady and loyal employment of its subjects. In order to ensure the validity and the reliability of the instrument, a preliminary study was created as a pilot test in order to test the validity of the survey questions. After having received favorable results, the researcher has decided that the instrument is not prone to other interpretations which may result to errors that reduce the accuracy and consistency of the instrument and the test scores. In future studies, the same instrument is seen to produce highly consistent and accurate test scores.

As far as the instrument, the researcher made sure that with regards to reliability, the study should be replicable when using another set of subjects. Secondly, the means of measurements can be assured as accurate since the study actually measured what the study intended to measure.

\section{FINDING AND DISCUSSIONS}

After the survey has been administered and after the responses were consolidated, integrated and compartmentalized into tables, this section will present the results and analyze them according to the aims of the research. In retrospect, the paper probes into the impact and the effect of HRM activities in the motivation, and directly, the loyalty of the employees to the organization. Among the general loyalty motivators, the answers of the surveyed participants are detailed in this segment.

\section{A. Section I: General Loyalty Motivator}

General loyalty motivators are perceived by the researcher as the foremost aspects of work that employees, on a superficial level, consider as important factors which affect their choice to stay or to leave the organization. In this section 
of the questionnaire, the respondents were asked regarding their opinions on the six major determinants of employeeloyalty.

TABLE I: GENERAL LOYALTY MOTIVATOR

\begin{tabular}{|c|c|c|c|c|c|c|c|}
\hline Criteria & 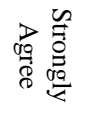 & $\underset{\substack{\infty \\
\overparen{8}}}{\infty}$ & 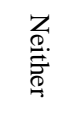 & 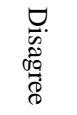 & 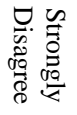 & Mean & SD \\
\hline $\begin{array}{l}\text { Office } \\
\text { environment }\end{array}$ & $\begin{array}{c}316 \\
(70 \%)\end{array}$ & $\begin{array}{c}77 \\
(17 \%)\end{array}$ & $\begin{array}{c}34 \\
(8 \%)\end{array}$ & $\begin{array}{c}13 \\
(3 \%)\end{array}$ & $\begin{array}{c}10 \\
(2 \%)\end{array}$ & 4.50 & .918 \\
\hline Compensation & $\begin{array}{c}351 \\
(78 \%)\end{array}$ & $\begin{array}{c}80 \\
(18 \%)\end{array}$ & $\begin{array}{c}14 \\
(3 \%)\end{array}$ & $\begin{array}{c}2 \\
(0 \%)\end{array}$ & $\begin{array}{c}2 \\
(0 \%)\end{array}$ & 4.82 & 1.986 \\
\hline $\begin{array}{l}\text { Amount of } \\
\text { change in the } \\
\text { organization }\end{array}$ & $\begin{array}{c}346 \\
(77 \%)\end{array}$ & $\begin{array}{c}65 \\
(14 \%)\end{array}$ & $\begin{array}{c}29 \\
(6 \%)\end{array}$ & $\begin{array}{c}5 \\
(1 \%)\end{array}$ & $\begin{array}{c}5 \\
(1 \%)\end{array}$ & 4.65 & .747 \\
\hline Office location & $\begin{array}{c}418 \\
(93 \%)\end{array}$ & $\begin{array}{c}21 \\
(5 \%)\end{array}$ & $\begin{array}{c}5 \\
(1 \%)\end{array}$ & $\begin{array}{c}2 \\
(0 \%)\end{array}$ & $\begin{array}{c}4 \\
(1 \%)\end{array}$ & 4.88 & .510 \\
\hline $\begin{array}{l}\text { Organization } \\
\text { benefits }\end{array}$ & $\begin{array}{c}336 \\
(75 \%)\end{array}$ & $\begin{array}{c}91 \\
(20 \%)\end{array}$ & $\begin{array}{c}14 \\
(3 \%)\end{array}$ & $\begin{array}{c}2 \\
(0 \%)\end{array}$ & $\begin{array}{c}7 \\
(2 \%)\end{array}$ & 4.66 & .708 \\
\hline $\begin{array}{l}\text { Career } \\
\text { development } \\
\text { prospects }\end{array}$ & $\begin{array}{c}356 \\
(79 \%)\end{array}$ & $\begin{array}{c}67 \\
(15 \%)\end{array}$ & $\begin{array}{c}20 \\
(4 \%)\end{array}$ & $\begin{array}{c}0 \\
(0 \%)\end{array}$ & $\begin{array}{c}7 \\
(2 \%)\end{array}$ & 4.70 & .698 \\
\hline
\end{tabular}

The office environment is an important factor which can affect the employee's attitude towards his employers because the workplace is where the creative process and the productive work happens. The office environment can spell the difference in the efficiency and the productivity of the employer. It can also affect their performance since many factors such as physical and mental distractions, ergonomics, lighting and ventilation can influence the thought process. Also, other factors such as space, interaction with co-workers and the overall working condition affect the way an employee performs.

Based on the survey, $70 \%$ of the total number of the respondents believe that the office environment is indeed an important factor. 0.92 values deviated from the mean in this particular criterion. Subsequently, the rest of the respondents were sporadically divided among all other options. Judging from the scores, a majority of the respondents strongly agree that office environment is an important motivator.

Compensation refers to something, typically money which is awarded to someone as a recompense for labor or services rendered. It is the money received by an employee from an employer as a salary or wage. Normally, one would think that the compensation is one of the most important motivating factor for the loyalty of the employees to their employers. The personal bias of the researcher is leaned towards believing that the criterion on the compensation or the salary derived from the job would generate an almost unanimous response from the respondents.

Although majority (78\%) of the respondents answered that they strongly agree to the assumption that compensation or pay is the most important motivator for workers to stay in service with their organizations, it does not necessarily pose as an absolute fact. $18 \%$ of the respondents agree that the compensation may be a factor for employee loyalty, and this might be because they consider other factors to be more important than the salary they derive from the work that they render. The values which deviated from the mean in this criterion is at 1.98 .

The amount of change in the organization best describes the variety and the dynamism at work that the employees get to enjoy. One thing that is very detrimental to the motivation of the employees is the feeling of stagnancy, and mechanical, routine work takes the fun out of working, so to speak. The amount of change in the organization also refers to the change of scenario in the work place to keep the employees from getting bored and lazy.

Majority $77 \%$ of the respondents of the study strongly agree that the amount of change in the organization is an important motivating factor, hence it matters in the retention of employees. With a standard deviation of 0.75 , employees are more likely to be loyal to an employer who has initiatives and methods which maintain the variety and promote dynamism within the workplace in order to stimulate the employees.

Logically, office location is important because one should choose a workplace which can offer utmost convenience. The office location, like the office environment can affect the efficiency and the performance of the employees. With 0.51 values deviating from the mean, office location shows to be an important factor that employees perceive as a motivating factor for them to stay with a certain organization. A near unanimous $93 \%$ of the respondents strongly agree with the assumption that workers value where their office is located. Only a marginal portion of the whole respondent pool answered that they only agree or even disagree that office location is a motivating factor.

In addition to the normal salary or the wages that employees derive from working for their own respective organizations, certain benefits which can motivate them to stick with their employers are composed of different fringe benefits. These benefits may include housing allowance, vehicles, insurance, income protection, reimbursements, sick leaves, profit sharing, education and other special perks and privileges that employers place on top of the salary.

Benefits differ from organization to organization, and one of the most common reasons why employees move from one organization to another is because of the perks and the benefits that other organizations have to offer. More often than not, employers place a premium in creating attractive perks and benefits packages to go with salary and pay as a reward for good performance.

The results show that only $75 \%$ of the respondents strongly agree that organization benefits can determine the retention and turnover rates for the organization. Favorably, this is an overwhelming majority, and all the other respondents with considerable deviations (0.71) from the mean either agree or strongly agree with the assumption that benefits do attract and encourage employees to stay with their respective organizations.

The criterion on career development prospects as a motivator for employee loyalty refers to the manner in which the organization lays out its plans for the promotions of its employees. It means the manner of how the organizations structure the career progress of their employees, and it can be also connected to the succession plan of the members of the organization or the manpower. Employees are often drawn in by promises of steady promotions, and stagnancy or 
immobility in current positions can be reasons for turnover.

According to the results of the survey, a majority of $79 \%$ strongly agree that career development prospects motivate them to stay with their organizations. $15 \%$ agree that organization promises of promotion encourage them to stay. With a meager 0.70 values deviating from the mean, one can safely say that prospects of career development keeps the employees from jumping ship.

\section{B. Section II: Personal Motivators}

TABLE II: PERSONAL MOTIVATORS

\begin{tabular}{|c|c|c|c|c|c|c|c|}
\hline Criteria & 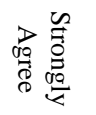 & $\underset{\substack{\infty \\
\mathbb{8}}}{\frac{1}{8}}$ & 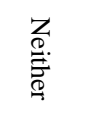 & 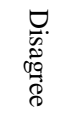 & 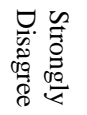 & Mean & SD \\
\hline $\begin{array}{l}\text { Work-life } \\
\text { balance }\end{array}$ & $\begin{array}{c}341 \\
(76 \%) \\
\end{array}$ & $\begin{array}{c}73 \\
(16 \%) \\
\end{array}$ & $\begin{array}{c}21 \\
(5 \%) \\
\end{array}$ & $\begin{array}{c}5 \\
(1 \%) \\
\end{array}$ & $\begin{array}{c}10 \\
(2 \%)\end{array}$ & 4.62 & .814 \\
\hline $\begin{array}{l}\text { Work } \\
\text { performance } \\
\text { and goal } \\
\text { achievement }\end{array}$ & $\begin{array}{c}351 \\
(78 \%)\end{array}$ & $\begin{array}{c}78 \\
(17 \%)\end{array}$ & $\begin{array}{c}12 \\
(3 \%)\end{array}$ & $\begin{array}{c}3 \\
(1 \%)\end{array}$ & $\begin{array}{c}6 \\
(1 \%)\end{array}$ & 4.70 & .681 \\
\hline Job Security & $\begin{array}{c}378 \\
(84 \%)\end{array}$ & $\begin{array}{c}32 \\
(7 \%)\end{array}$ & $\begin{array}{c}26 \\
(6 \%)\end{array}$ & $\begin{array}{c}2 \\
(0 \%)\end{array}$ & $\begin{array}{c}12 \\
(3 \%)\end{array}$ & 4.69 & .822 \\
\hline $\begin{array}{l}\text { Further } \\
\text { leaning }\end{array}$ & $\begin{array}{c}326 \\
(72 \%) \\
\end{array}$ & $\begin{array}{c}70 \\
(16 \%) \\
\end{array}$ & $\begin{array}{c}39 \\
(9 \%) \\
\end{array}$ & $\begin{array}{c}5 \\
(1 \%) \\
\end{array}$ & $\begin{array}{c}10 \\
(2 \%) \\
\end{array}$ & 4.55 & .869 \\
\hline $\begin{array}{l}\text { Job and } \\
\text { organization } \\
\text { goal linkages }\end{array}$ & $\begin{array}{c}146 \\
(32 \%)\end{array}$ & $\begin{array}{c}62 \\
(14 \%)\end{array}$ & $\begin{array}{c}231 \\
(51 \%)\end{array}$ & $\begin{array}{c}11 \\
(2 \%)\end{array}$ & $\begin{array}{c}0 \\
(0 \%)\end{array}$ & 3.76 & .939 \\
\hline $\begin{array}{l}\text { Creative } \\
\text { opportunities }\end{array}$ & $\begin{array}{c}383 \\
(85 \%)\end{array}$ & $\begin{array}{c}54 \\
(12 \%)\end{array}$ & $\begin{array}{c}7 \\
(2 \%)\end{array}$ & $\begin{array}{c}3 \\
(1 \%)\end{array}$ & $\begin{array}{c}3 \\
(1 \%)\end{array}$ & 4.80 & .557 \\
\hline
\end{tabular}

A good balance between work and personal life can save an employee from burning out. Spending quality time outside of the work place in activities which promote stress relief, exercise and bonding with family and friends can be very healthy for a worker. For the study, the questionnaire asked the pool of respondents to rate how work-life balance motivates them to stay, and in this regard, it goes back to how the organization provides workload and the amount of tasks assigned to their employees.

For work-life balance, $76 \%$ of the respondents answered that they strongly agree that the criterion is an important motivator. They would like to work for a organization who expects productivity from the employees yet they provide just the right amount of workload with fairly reasonable deadlines, or achievable and workable goals and objectives for a period of time. The majority believe that work-life balance, and the standard deviation of 0.81 is an indication that despite dissentions from the majority, a great portion of the pool of respondents strongly agree to the assumption of work-life balance as affected by the organization's goals as a reason to stay or to leave.

In order for the employees to feel valued, and in order for them to feel that they are of worth, the work performance and the achievement of their own personal goals and objectives should be put into consideration.

The results of the study, as illustrated by the table above show that $78 \%$ or an overwhelming majority among the surveyed population strongly agree that work performance and the achievement of goals affect their decision to stay or to leave the organization.
Job security refers to the chances that a certain employee will keep his job or position. It assures that a person will not be unemployed. In the current situation of the economy, job security should be the number one factor that employees will consider when contemplating on their choices, as more and more employees are being laid-off or relieved of their positions due to cost-cutting, especially through off shoring or outsourcing. A worker's decision to stay or to leave a organization can be affected by the threat of unemployment.

The table shows that $84 \%$ of the surveyed participants believe that job security is an important reason why people leave or stay with their organizations. Recent changes and developments in the economic situation has left an air of panic or even desperation, and in terms of job security, employers would inexorably choose the employer which can guarantee them a job despite the shaky and fragile economy.

The deviation from the mean in this criterion is 0.82 , which means that only a small portion of the tested subjects do not strongly agree to the assumption the job security is personal motivating factor which can affect employee loyalty.

Another criterion is further learning, which basically means the amount of further education or training that employees derive from their work. Education does not stop at school, and the learning experience that workers get from their employers can also be a reason for them to stay loyal with their organizations.

Also, The table shows that $72 \%$ of the respondents strongly agree that further learning can motivate the employees to stay. The SD of the responses is at 0.87 . On the contrary, the next criterion which is job and organization goal linkages, or the extent of the linkage of the organization's objectives to that of the personal interests of a worker, shifted the pattern dramatically. As the table evidences, over half of the population have neutral views on the assumption that the connection of the organization or the organization's goals and objectives to those of the personal goals of the employees themselves. 51\% responded with "neither agree nor disagree" in the questionnaire, and judging on the 0.94 values which deviated from the mean of 3.7, it is apparent that this criterion does not have any bearing to the decision of the employees to stay or leave their organizations. The last criterion among the personal motivators of employees is creative opportunities. It refers to how much the opportunity the employee has in contributing to the betterment of the team or the workplace.

The table shows that a majority (85\%) of the respondents strongly agree that they would be loyal to an employer who provides them with opportunities of contributing their creative ideas and concepts to the group. The deviation which is at 0.56 suggests that a great portion of the population make up the majority. The focus of the study is to take a look at the HRM activities and initiatives which encourage employees to remain with the organization. The next segment will focus more on the HR related-factors which can affect the retention of the employees.

\section{Section III: HR Relations}

The survey results showed that $73 \%$ of the respondents strongly agree that HR attitude towards their employees are important. Conversely, almost similar results are produced by 
the criterion on the behavior and the skills of HR, which hare rated at $77 \%$ and $76 \%$ respectively. On the other hand, the criterion of internal communication with HR resulted with $84 \%$ of the total population strongly agreeing to the assumption that close correspondences with the HR department encourage employees to stay. $87 \%$ of the respondents of the study believe that recognition and praise from the HR may yield positive results in the area of employee retention. As far as cooperation from the HR department is concerned, a near-unanimous majority of $90 \%$ strongly agree that HR assistance in every step of employment may help retain employees.

TABLE III: HR RELATIONS

\begin{tabular}{|c|c|c|c|c|c|c|c|}
\hline Criteria & 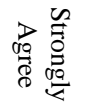 & $\underset{\substack{\sigma 0 \\
\overparen{0}}}{\overrightarrow{0}}$ & 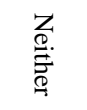 & 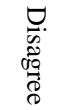 & 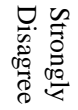 & Mean & SD \\
\hline $\begin{array}{l}\text { Attitudes of } \\
\text { HR towards } \\
\text { employees }\end{array}$ & $\begin{array}{c}329 \\
(73 \%)\end{array}$ & $\begin{array}{c}40 \\
(9 \%)\end{array}$ & $\begin{array}{c}60 \\
(13 \%)\end{array}$ & $\begin{array}{c}11 \\
(2 \%)\end{array}$ & $\begin{array}{c}10 \\
(2 \%)\end{array}$ & 4.48 & .965 \\
\hline $\begin{array}{l}\text { Behavior of } \\
\text { HR }\end{array}$ & $\begin{array}{c}348 \\
(77 \%)\end{array}$ & $\begin{array}{c}66 \\
(15 \%)\end{array}$ & $\begin{array}{c}29 \\
(6 \%)\end{array}$ & $\begin{array}{c}4 \\
(1 \%)\end{array}$ & $\begin{array}{c}3 \\
(1 \%)\end{array}$ & 4.67 & .696 \\
\hline Skills of HR & $\begin{array}{c}340 \\
(76 \%)\end{array}$ & $\begin{array}{c}85 \\
(19 \%)\end{array}$ & $\begin{array}{c}20 \\
(4 \%)\end{array}$ & $\begin{array}{c}3 \\
(1 \%)\end{array}$ & $\begin{array}{c}1 \\
(0 \%)\end{array}$ & 4.70 & .617 \\
\hline $\begin{array}{l}\text { Internal } \\
\text { communicatio } \\
\text { n with HR }\end{array}$ & $\begin{array}{c}378 \\
(84 \%)\end{array}$ & $\begin{array}{c}57 \\
(13 \%)\end{array}$ & $\begin{array}{c}7 \\
(2 \%)\end{array}$ & $\begin{array}{c}3 \\
(1 \%)\end{array}$ & $\begin{array}{c}5 \\
(1 \%)\end{array}$ & 4.78 & .615 \\
\hline $\begin{array}{l}\text { Recognition } \\
\text { and praise }\end{array}$ & $\begin{array}{c}392 \\
(87 \%)\end{array}$ & $\begin{array}{c}38 \\
(8 \%)\end{array}$ & $\begin{array}{c}14 \\
(3 \%)\end{array}$ & $\begin{array}{c}4 \\
(1 \%)\end{array}$ & $\begin{array}{c}2 \\
(0 \%)\end{array}$ & 4.81 & .569 \\
\hline $\begin{array}{l}\text { Cooperation } \\
\text { from HR }\end{array}$ & $\begin{array}{c}404 \\
(90 \%\end{array}$ & $\begin{array}{c}31 \\
(7 \%)\end{array}$ & $\begin{array}{c}11 \\
(2 \%)\end{array}$ & $\begin{array}{c}4 \\
(1 \%)\end{array}$ & $\begin{array}{c}0 \\
(0 \%)\end{array}$ & 4.86 & .476 \\
\hline
\end{tabular}

\section{Section IV: HR and Management Activities Motivators}

The last set of questions and criteria are under the HR and management activities motivators. The criteria in this group are composed of personal and professional communication, motivation techniques, competence and skills, appraisals and personal development, influencing style, leadership skills and lastly, clear goals and objectives.

\section{TABLE IV: HR AND MANAGEMENT ACTIVITIES MOTIVATORS}

\begin{tabular}{|c|c|c|c|c|c|c|c|}
\hline Criteria & 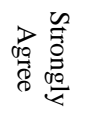 & 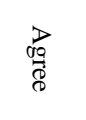 & 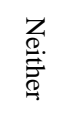 & 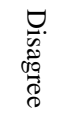 & 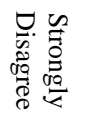 & Mean & SD \\
\hline $\begin{array}{l}\text { Personal and } \\
\text { Professional } \\
\text { Communication }\end{array}$ & $\begin{array}{c}338 \\
(75 \%)\end{array}$ & $\begin{array}{c}50 \\
(11 \%)\end{array}$ & $\begin{array}{c}42 \\
(9 \%)\end{array}$ & $\begin{array}{c}12 \\
(3 \%)\end{array}$ & $\begin{array}{c}8 \\
(2 \%)\end{array}$ & 4.55 & .900 \\
\hline $\begin{array}{l}\text { Motivation } \\
\text { Techniques }\end{array}$ & $\begin{array}{c}317 \\
(70 \%)\end{array}$ & $\begin{array}{c}59 \\
(13 \%)\end{array}$ & $\begin{array}{c}37 \\
(8 \%)\end{array}$ & $\begin{array}{c}9 \\
(2 \%)\end{array}$ & $\begin{array}{c}28 \\
(6 \%)\end{array}$ & 4.40 & 1.128 \\
\hline $\begin{array}{l}\text { Competence and } \\
\text { Skills }\end{array}$ & $\begin{array}{c}357 \\
(79 \%) \\
\end{array}$ & $\begin{array}{c}65 \\
(14 \%) \\
\end{array}$ & $\begin{array}{c}15 \\
(3 \%) \\
\end{array}$ & $\begin{array}{c}3 \\
(1 \%) \\
\end{array}$ & $\begin{array}{c}10 \\
(2 \%)\end{array}$ & 4.68 & .770 \\
\hline $\begin{array}{l}\text { Appraisals and } \\
\text { Personal } \\
\text { Development }\end{array}$ & $\begin{array}{c}381 \\
(85 \%)\end{array}$ & $\begin{array}{c}47 \\
(10 \%)\end{array}$ & $\begin{array}{c}12 \\
(3 \%)\end{array}$ & $\begin{array}{c}5 \\
(1 \%)\end{array}$ & $\begin{array}{c}5 \\
(1 \%)\end{array}$ & 4.76 & .659 \\
\hline Influencing style & $\begin{array}{c}312 \\
(69 \%) \\
\end{array}$ & $\begin{array}{c}93 \\
(21 \%) \\
\end{array}$ & $\begin{array}{c}28 \\
(6 \%) \\
\end{array}$ & $\begin{array}{c}8 \\
(2 \%) \\
\end{array}$ & $\begin{array}{c}9 \\
(2 \%) \\
\end{array}$ & 4.54 & .849 \\
\hline $\begin{array}{l}\text { Leadership } \\
\text { Skills }\end{array}$ & $\begin{array}{c}247 \\
(55 \%)\end{array}$ & $\begin{array}{c}44 \\
(10 \%)\end{array}$ & $\begin{array}{c}144 \\
(32 \%)\end{array}$ & $\begin{array}{c}6 \\
(1 \%)\end{array}$ & $\begin{array}{c}9 \\
(2 \%)\end{array}$ & 4.14 & 1.041 \\
\hline
\end{tabular}

In terms of personal and professional communication, the results of the survey came out with $75 \%$ of the respondents strongly agreeing to the assumption that the personal and professional communication activities from the employer to the employers are important motivators. Subsequently, the results for motivation techniques and competence and skills are at $70 \%$ and $79 \%$ strongly agreeing to the respective assumptions. In terms of appraisals and persona development, the respondents who strongly agree are at $85 \%$. Influencing style is at $69 \%$ for the most affirmative choice, and with leadership at $55 \%$ respondents agreeing that superb leadership is also an HR and management activity-related motivator. Lastly, clear goals and objectives are ranked at $71 \%$ strongly agreeing respondents who believe that a organization with clear directions and aims retain more employees out of loyalty.

The results of the survey generally favored the Strongly Agreed component of the answers, and what this means is that for all the listed criteria, the employees would like their organizations to provide such initiatives, components and activities. In order for employees to stay with their respective organizations, the organizations should provide a maximum level of motivation. Basically, the results of the survey tell us that it is important for the organization to provide the necessary avenues and channels so that they can reach out to their employees in the best way that they can.

\section{CONClusion}

Factors which motivate employees to stay in the organization are important elements in the workplace. Even more important is the assurance of a steady pool of loyal employees. Some of the said factors might be perks and privileges that the organization could provide at low expense and with a little budget, or they might be large-scale program overhauls and restructuring in order to accommodate the staffing requirements which can give way to the promotion of deserving individuals. Whatever they may be, motivators which come in the form of activities conducted by a organization's HR department indeed affect the retention and turnover rates of their employees.

As established by the results of the study, the 25 factors which were listed in the questionnaire as categories of motivation from the employers and the HR department to the employees have brought about a certain extent of motivation which can affect the employees' resolve to stay with the organization, or to seek employment elsewhere where they can have more of what they need. When a certain employer provides the needs of its employees, it almost guarantees for itself a steady and patronizing pool of employees.

Employees look to their organizations to fill in their needs for certain aspects in their professional life. The compensation given is of course, imperative. However, more important than salary or the pay that employers provide to their subjects which can provide more fulfillment than money. Needless to say, money or monetary compensation is important, but what employees need more is the support and the motivation which can encourage them to enjoy their current job. What is in it for the organization is they get to avoid the costs associated wit training new employees in case of turnovers or when someone moves to another organization. 
For organizations who lack some areas of motivating their employees to stay loyal to the organization, it is important to put in reforms in their policies as well as in their operation plans. It is essential for organizations to grant maximum fulfillment and contentment as these are great investments that will turn out to benefit the organizations in the long run. organizations should provide for the fulfillment of their employees in order to engage them in providing results. There is an inexorable link between contentment and job satisfaction and loyalty and positive outcomes. The fulfillment of the factors of motivation bolster the opportunities enjoyed by the employees, and they can participate in a variety of pursuits so that they can offer their creativity and efficiency more to their employers.

In retrospect, the paper covered the factors and the criteria which comprise the motivation of employees to stay loyal with their employers. It is essential to emphasize that at times like these when the economy is in a tight situation, organizations need to retain competent and hard-working employees. Manpower is valuable, and the pool of competent professionals that a organization has working for them can make or break the success of the organization. The paper engaged in a quantitative study which surveyed 450 employees. In the end, the paper concludes that motivation and employee satisfaction is very important in retaining employees.

\section{REFERENCES}

[1] Y. Kondo, Human Motivation: A Key Factor for Managemen, Tokyo: 3A Corporation, 2009.

[2] J. Carsen, HR How to: Employee Retention, 1 ed. Chicago: $\mathrm{CCH}$ Knowledgepoint, 2002.

[3] B. Kaye, Love 'em or Lose 'em: Getting Good People to Say, San Francisco: Bennett-Koehler Publishings, 2008.
[4] L. McKeown, Retaining Top Employees, New York: McGraw Hill, 2002.

[5] N. M. Aladily, Managing Organizational Behavior, Riyadh: Marmar, 2005, ch 4, pp. 176- 221.

[6] N. Borkowski, Organizational Behavior in Health Care, Chicago: Jones and Bartlett, 2011.

[7] S. J. Lauby, Sharlyn J. L.. Fort Lauderdale: ASTD Press, 2005.

[8] K. S. Alarif, "Job satisfaction in private sector in Saudi Arabia," Conference on Future Work Forces in Arab World, Arab Labour Organization, Dubai, March 4-5, 2010.

[9] C. Corpuz, Human Resource Management, Edition ed. Manila: Rex Bookstore, 2006.

[10] A, Sacco. (2006). Tech workers' loyalty on the rise: study. [Online]. Available:

http://www.itworldcanada.com/news/tech-workers-loyalty-on-the-rise -study/98281.

[11] M. Drizin, (2002). Employee Loyalty Research: Case Studies. [Online]. Available: http://crmguru.custhelp.com/app/answers/detail/a_id/214/ /employeeloyalty-research\%3A-case-studies.

[12] C. Woolard, ( 2011). 12 Aspects of a Great Place to Work. [Online]. Available: http://blog.walkerinfo.com/blog/loyalty-in-the-workplace/12-aspectsof-a-great-place-to-work-aspects-1-6.

[13] M. N. Saunders, A. Thornhill, and P. Lewis, Research Methods for Business Students, New York: Financial Times Prentice Hall, 2009.

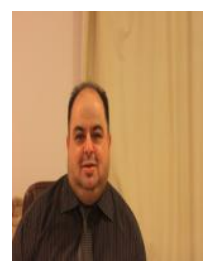

Sami Albahussan was born in Dammam, Saudi Arabia in April 1966. He holds a BA in Project Management from King Faisal University in 1989, Saudi Arabia, and MSc in Management and Organization from the University of Colorado at Denver, Colorado, USA in 1994, and a doctorate from the University of Bradford, UK in HRM in 2000. He is an Associate Professor in Human Resources Management, and Chair of Business Administration Dept. at College of Business Administration, University of Dammam. His research interests lie in the area of human resources management, Organizational development, organizational behavior, and Business Ethics. 